\title{
Aedes aegypti Vulnerability Status of $0.8 \%$ Malathion Insecticides in 8 Districts in South Kalimantan Province
}

\author{
Nita Rahayu ${ }^{1}$, Dicky Andiarsa ${ }^{2}$, Yuniarti Suryatinah3, Gusti Meliyanie ${ }^{4}$, Sri \\ Sulasmi $^{5}$, Harninda K. Ningtyas ${ }^{6}$ \\ \{nita.rahayu79@yahoo.co.id, andiarsa@gmail.com, yuniarti_suryatinah@gmail.com\} \\ ${ }^{1}$ Tanah Bumbu National Agency of Health Research and Development
}

\begin{abstract}
Dengue Hemorrhagic Fever (DHF) is one of the many health problems that occur in Indonesia and it's increasingly widespread. This study conducted a susceptibility test for mosquitoes Aedes aegypti against insecticides used in the province of South Kalimantan. Larva capture surveys, environmental observations in 300 houses in each districts province (each district represented by 3 endemic health center work areas) in South Kalimantan province. The larvae obtained by reared until the adult mosquito is of the third progeny (F3) and then tested against Malathion insecticide $0.8 \%$ ). The results of the Malathion susceptibility $0.8 \%$, in 8 districts in the Province of South Kalimantan illustrate the conditions of resistance in all regions. In addition, the results of the susceptibility test showed that the Aedes aegypti mosquito was $0.8 \%$ Malathion resistant. Therefore, it is recommended that a program be able to intensify the PSN movement, rotation of insecticide active ingredients, supervision of technical officers or larvae monitors.
\end{abstract}

Keywords: Vulnerability, Aedes aegypti, Insecticide

\section{Introduction}

Dengue Fever (DBD) is a disease caused by dengue virus that is included in the Flavivirus genus of the Flaviridae famili. The Virus is transmitted by several species of mosquitoes, namely Aedes aegypti, Aedesalbopictus and Aedes Scutellaris, but most commonly reported to be the dominant vector is Ae. Aegypti.[1]

The incidence of DBD in urban areas also demonstrates the vulnerability of environmental, social and economic conditions that have decreased nutritional status so that it is easily infected with disease. This is related to the pattern of land use, population density, urbanization, in addition to the low effort DBD vector control efforts early on, resistance to the possibility of appearance of strains or other types of viruses. Aedes aegypti resistance to insecticide is a global phenomenon, especially the maintainer of the Vector disease control program in Indonesia. Resistance is derived and is a single obstacle in the success of chemical vector control. [2]

Some vector control methods have been widely known and used by DBD control programs at the central and regional level of: Environmental management, biological control, chemical 
control, community participation, individual protection and regulatory legislation. DBD control is primarily aimed at disconnecting the transmission chain, which is by controlling the vectors. The occurrence of resistance will cause problems because insects that have been resistant will reproduce and there will be genetic changes that lower their resistance (Filialnya), which will eventually increase the proportion of resistant vectors in Population. Vector vulnerability testing aims to determine the status and map of the vulnerability of vector species to insecticides that have been and will be used for vector control in deployment areas with the same epidemiology. It is used as a basis in regulating the use of insecticide in vector control. [3]

In Indonesia, used of malathion and temephos as an insecticide in the national program of DBD Control since 1970. One of the determinants of the application effectiveness of the second insecticide is the vulnerability of vector mosquitoes in both the larvae and adult stage.

In some areas of Indonesia, this type of insecticide is still used and is considered effective in the control of DBD. But the impact of the use of these two insecticide based organophosphate is carried out continuously is the danger of mosquito-resistance vector DBD. (4) It is based on the statements Georgio and Melon which mentions that use of chemical insecticide in the long term with a high frequency per year will gradually suppress and select insects (mosquito vector) targets to be tolerant until resistant to it. [5]

Vector control chemically, especially vector control using insecticide in adult mosquitoes will stimulate the occurrence of selection in the target population of insects. Use of intensive and uncontrolled insecticides, causing insect resistance to insecticides is more rapidly occurring. As a result if insects have been resistant to insecticides, control failures will occur. [4] Continuous insecticide application of insects, especially Ae. Aegypti can produce tolerant individuals even immune to these insecticides. Research conducted in Yogyakarta and Central Java showed a tendency to decrease the vulnerability of Ae. Aegypti against malathion in an area that is often applied with malathion. [4]

The emergence of resistant insect properties is triggered by prolonged exposure. This occurs because of an Ae mosquito. Aegypti is able to develop an immune system against insecticide that is often used. [4]

Success control of vector DBD depends on the status of vector resistance to the insecticide used. The purpose of this research is to determine the status of mosquito resistance Ae. Aegypti against malathion $0.8 \%$ in 8 regency/city of South Kalimantan province. The result of this research illustrates the status of vulnerability of DBD vector against malathion insecticide in 8 regencies/cities in South Kalimantan province.

\section{Research Method}

Research is a descriptive study using the design approach of cross sectional. The research activity includes secondary data tracing of DBD cases in South Kalimantan province in the last 3 years. Survey entomology (survey of visual criminal arrest), observation of the environment and interviews the use of household insecticide in 300 houses in each district/city (each district is represented by three centers of health Puskesmas endemic) province of South Kalimantan. The larvae obtained by reared until the adult mosquito is of the third progeny (F3) and then tested against Malathion insecticide 0.8\%). This research has performed in April - December 2016.

Test of the vulnerability of adult mosquitoes tested is the Ae mosquito, Ae. Aegypti, 3rd Gen Albopictus Female (F3), with the same age relatively in the stomach condition full of satiety sugar liquid. The phase of the vulnerability test is to provide 2 tubes that are colored red 
spots for treatment and 2 green spot tubes for control. Into the 2-tube treatment of impregnated paper (insecticide paper) according to the insecticide and the dose used, while into the control tube, input the paper with the oil Risela. Provide 4 tubes with green spots for acclimatization and observation of mosquito death. Into each tube with green spots input 25 mosquito-tailed Ae. Aegypti/Ae albopictus females to be tested. Left for 1 hour for acclimatization. When there is mosquito that dies/defects when acclimatization is not included in the calculation. An Ae. Aegypti/Ae. Albopictus is removed from green freckle tube to red spot tubes for treatment and green spot tubes for control. Mosquitoes are allowed to contact with insecticide or risela oil for 60 minutes. Mosquitoes are transferred back to green spots which are not insecticide, then maintained and observed for 24 hours. Observed and noted mosquitoes are knock down or die at a minute to $5,10.15,20,25,30$, and 60 . To maintain moisture and temperature in the maintenance chamber, the tubes containing the observed mosquito, are inserted into the confinement and covered with a damp towel. During the test and observation, recorded temperature, humidity in the temperature of $\mathrm{max} / \mathrm{min}$ and sling hygrometyer. [2]

In this test if the death of mosquitoes in the control $\geq 10 \%$, then for the correction factor should be used ABBOTS formula. The mapping of the vulnerabilities that will be generated in the study is the vulnerability status of each Regency/city, i.e. vulnerable, tolerant, and resistant, which will be visualized in overlay. [6]

Analysis of mosquito vulnerability to malathion was carried out by calculating the number of mosquitoes that died on an hour and 24 hours after exposure with the paper on insecticide active ingredient malathion $0.8 \%$ (impregnated paper). If the death of mosquito $>98 \%$ then the mosquito is still vulnerable. Death $80 \%-98 \%$ the condition is tolerant. While the death of $<80 \%$ then the mosquito is expressed resistant. [6]

\section{Results}

The use of an Ae. Aegypti control insecticide in research for the location of the insecticide use is a part that is not separated from the DBD vector control efforts in the area endemic DBD. In some districts problematic DBD, insecticides are selectively used one of them because of the limited budget available from the APBD fund, but some districts use insecticide for control of DBD vector because of the needs of the program. The often-used organophosphat is malathion and the often-employed pyrethoid sinthetic Group is Lambdasihalotrin, Sipermethrin. Even in some regions also found NGOS who do fogging using insecticides without coordination with local health agencies, without the thought of the consequences. This type of insecticide used in eight regencies/cities in 2013 most uses synthetic pyrethroids groups such as Lambdasihalotrin and Sipermitrin, while for the last three years there are still in four districts of research site using an organopospat group of active ingredients of malathion.[3]

Residents with self-sufficient funds attempt to perform DBD vector control measures independently by using household insecticide. The fact describes so many types of insecticides used for the control of Ae. Aegypti, not to mention household insecticide used by everyday communities such as mosquito-burning drugs with active ingredient Mosquitoes Coil (MC)insecticide, and Transflutrin $0.03 \%$, Sipermitrin $1.100 \%$, imiprotin $0.031 \%$, Praletrin $0.030 \%$ andaerosol/spray containing the active ingredient: D-Fenotrin $0.125 \%$, Praletrin $0.100 \%$, Sipermitrin $0.100 \%$, Permethrin $0.15 \%$, as well as types of mosquito repellent with The active ingredient is Diethytoluamide, Methylumiade13\%. [3]

Resistance test is implemented in the entomology laboratory of Tanah Bumbu National Agency of Health Research and Development. Resistance test implemented for 4 months. Its 
implementation is in September until December. Resistance test using Aedes aegypti mosquitoes of third derivative adults. Results of mosquito resistance Aedes aegypti against insecticide with active ingredient malathion $0.8 \%$ in 8 Regency/city of South Kalimantan Province shows has been resistant to the death percentage of Banjarmasin 28\%, Banjar 26\%, Balangan 31\%, Tabalong 32\%, Tapin 27\%, Hulu Sungai Selatan 25\%, Hulu Sungai Tengah $28 \%$, and Hulu Sungai Utara $23 \%$.

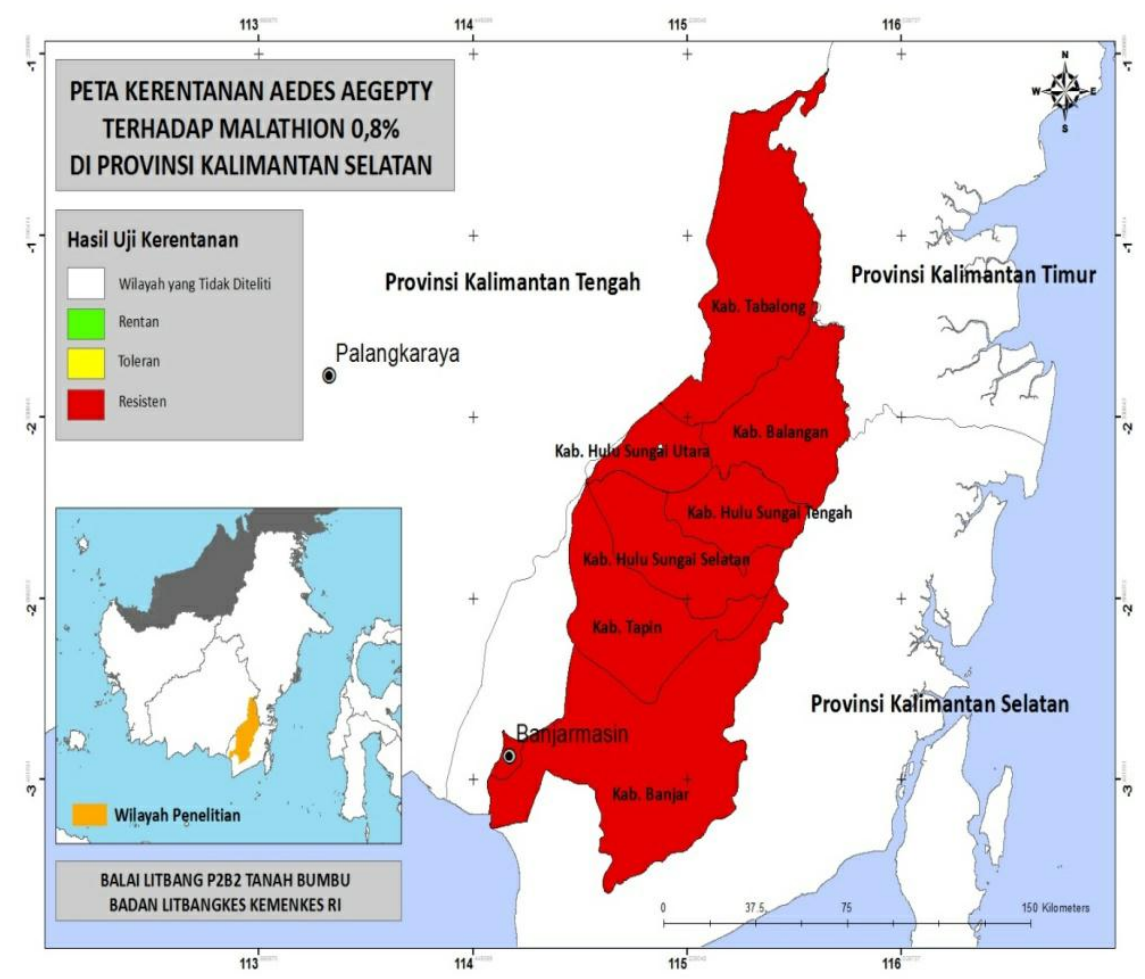

Figures 1. Map of Aedes aegypti vulnerabilities against Malathion $0.8 \%$

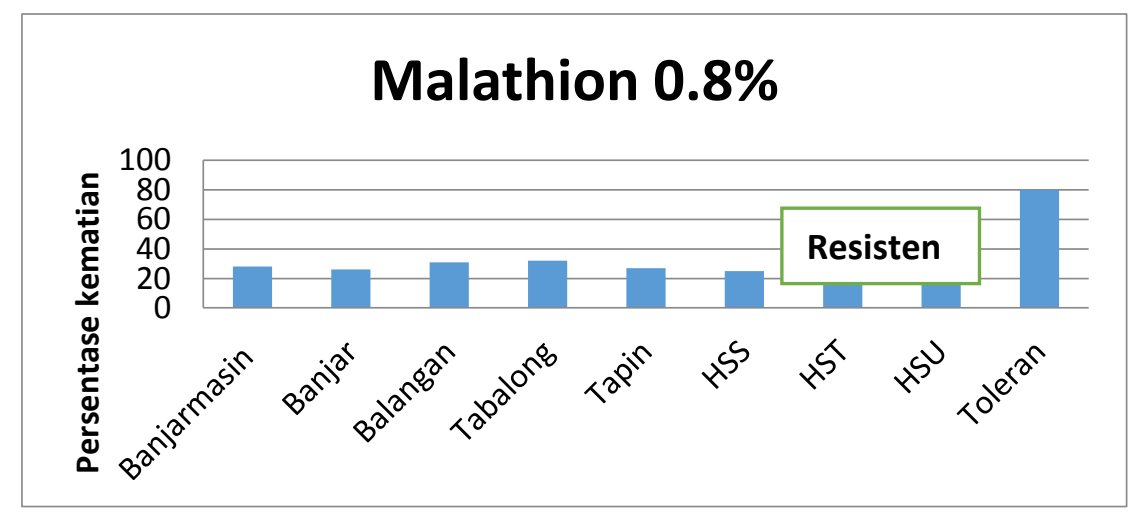


Figures 2. Graph of percentage of test mosquito mortality against Malathion $0.8 \%$

Results of mosquito resistance Aedes aegypti against insecticide with active ingredient malathion $0.8 \%$ in 8 regency/city of South Kalimantan Province shows has been resistant to the death percentage of Banjarmasin 21\%, Banjar 27\%, Balangan 30\%, Tabalong 4\%, Tapin 22\%, Hulu Sungai Selatan 8\%, Hulu Sungai Tengah 18\%, and Hulu Sungai Utara $62 \%$.

\section{Discussion}

The result of entomology survey is a series in collection of mosquito and done in eight regencies/cities in South Kalimantan province shows the existence of the habitat for the breeding of Aedes aegypti mosquitoes in general is still a problem related to DBD transmission.[7]

Environmental awareness already owned by community, because DBD control is not a health task but also in need of community participation. Public negligence in managing his home environment proved by the discovery of mosquito repellents in tubs, buckets, aquariums and washbasins. Because the objects are supposed to be cleaned regularly at least once a week. [7]

Another effort that needs to be done is the intervention in the form of vector control, but should pay attention to the possibility of the insecticide material used whether it is still sensitive to kill this vector. The insecticide malathion is an insecticide that has long been used by the vector control Program of DBD Ae. aegypti more than 10 years with application/fogging, especially in the area that is happening KLB. But in some areas there have also been found ongovernmental organizations (LSM) that performs vector control (fogging) without coordination with the local health service using insecticides that they consider to cope with mosquito bites, without thinking about the impact it causes. Even the public with a self-effort to try to conduct self-control measures in an unsafe manner. The fact illustrates that in the community environment many types of insecticide can be used for control Ae aegypti, and can also be used also by the people daily. This has an impact on the Ae aegypti vulnerability to certain insecticides. In fact there is a Regency/city that in the last three years using insecticide groups that are classified need strict supervision of an Organokhlorin group insecticide, whereas this insecticide has not been recommended since 1990 for control Ae. Aegypti. [4]

Test results susceptibility to determine the Ae. Aegypti vulnerability against insecticides used fogging with Malathion $0.8 \%$ apparently in four districts the research site has been resistant. This happens as one of the insecticide has been used in a period of more than 3 years with a high frequency.

The use of household insecticide is also often used by the public, as it is known that some household insecticide either with the formulation of aerosols and other formulations sometimes using malathion active ingredient and active ingredient Others like Propoxur (Bendiocarb) so that it can cause double resistance. [2]

Ae. Aegypti resistance to Malathion has also been conducted research in Malaysia by Hidayati Hamdan (2005), that after exposure to the insecticide malathion, Permethrin and Temephos during the 32 generations have been resistance. [1]

Malathion belongs to the organophosphate. Esterases are classified in a group of hydrolase enzymes, one large group of enzymes that catalyze the reaction of hydrolisa compounds to the alifatik, aromatic ester, choline ester and Organophosphorus. Esterases react with perfectly dissolved molecules in the water. This enzyme is able to break down cholesterol and is instrumental in the process of insect resistance to insecticide from organophosphate.[6] 
Resistance caused by enzyme activity occurs when the enzyme obstructs the insecticide compounds to reach its target side. Research by [3] shows that resistance to malathion on Culex quinquefasciatus and Cx. Tritaeniorhynchus relates to the increased activity of esterases. The presence of an increase in esterases enzymes indicates the detoxification metabolic mechanism in the body.[8] The results of susceptibility test against insecticide synthetic pirethroids group such as Permethrin $0.25 \%$ in four regencies/cities in Central Java apparently there is also a tendency resistant. Secara umum insektisida kelompok sintetik pirethroid sudah lama digunakan di Indonesia yaitu insektisida yang dicampurkan untuk pencelupan kelambu, insektisida kelompok ini juga sebagian besar digunakan untuk insektisida rumah tangga, namun pada golongan insektisida sintetik pirethroid jenis sipermitrin sudah banyak digunakan oleh program untuk pengendalian vektor DBD secara fogging. In general, the insecticide of synthetic Pirethroids group has long been used in Indonesia, namely insecticide mixed for mosquito netting, the insecticide of this group is also mostly used for household insecticide, but in group Synthetic insecticides Pirethroids type Sipermitrin is already widely used by the program for the control of DBD vectors in fogging. Insecticide synthetic Pirethroids group has the same target site as the insecticide of the Organochlorin group. The Organoclorin Group One example is DDT, it has been banned from being persistent in nature and difficult to unravel and carcinogenic. [3] It's in line research [9] Vector Fever Dengue Ae. Aegypti in 3 regencies/cities in South Kalimantan province has been resistant to: malathion $0.8 \%$, Lambdasihalotrin $0.03 \%$, Cypermethrin $0.05 \%$, and Deltametrin $0.025 \%$. The main cause of resistance is the use of the same type of insecticide over a long period of time. Rotational use of insecticide with different types of active ingredients in a certain period of time and pay attention to the dosage size, target, and also the correct timing.

\section{Conclusion}

The results of Aedes aegypti vulnerability test shows in eight regencies/cities South Kalimantan Province has been resistant to malathion 0.8 .

\section{Suggestions}

Need to immediately rotation of the use of insecticide for use in vector DBD control, especially in areas with vectors (Aedes aegypti) has been resistant.

\section{Acknowledgements}

On this opportunity the author thanked the head of National Agency of Health Research and Development who have provided funds to conduct research, the head of Tanah Bumbu National Agency of Health Research and Development who has given the trust to conduct research who have given confidence to conduct research, researchers and engineering staff who help the implementation of this research, the head of health departement office of South Kalimantan, health departement office regencies/city which is used as sample research of the 
permission the assistance and cooperation during the implementation of this research took place, all parties who have helped so that the research can run smoothly.

\section{References}

[1] Tasane I. Uji Resistensi Insektisida Malathion 0,8\% terhadap nyamuk Aedis aegypti di Wilayah Fogging Kesehatan Pelabuhan Kelas II Ambon. J Kesehat Masy. 3(April):16274. (2015).

[2] Ri KK. Pedoman Penggunaan Insektisida (pestisida) dalam pengendalian Vektor. 1-135 p. (2012).

[3] Ikawati B, Widiastuti D. Peta status kerentanan Aedes aegypti ( Linn .) terhadap insektisida cypermethrin dan malathion di Jawa Tengah. 7(1):23-8. (2015).

[4] Soenjono SJ, Pandean M. Status Resistensi Vektor Demam Berdarah Dengue Aedes aegypti terhadap Malathion di Kota Tomohon Resistance Status of Aedes aegypti Against Malathion , in Tomohon City. (April 2016):43-8.(2017).

[5] Prasetyowati H, Hendri J, Wahono T. Status Resistensi Aedes aegypti (Linn.) terhadap Organofosfat di Tiga Kotamadya DKI Jakarta The Resistance Status of Aedes aegypti (Linn.) to Organophosphate in Three District Jakarta. p23-30.(2016).

[6] world health organization. Test procedures for insecticide resistance monitoring in malaria vector mosquitoes Second edition. (2018).

[7] Ridha MR, Nisa K. Larva Aedes aegypti Sudah Toleran terhadap Temepos di Kota Banjarbaru, Kalsel, Tahun. 1976;III(2):93-111. (2001).

[8] Widiarti, Heriyanto B, Boewono DT, Widyastuti U, Mujiyono, Lasmiati, et al. Peta Resistensi Vektor Demam Berdarah Dengue. 2-14:6-7. (2011).

[9] Rahayu N, Sulasmi S, Suryatinah Y. Status kerentanan Aedes aegypti terhadap beberapa golongan insektisida di Provinsi Kalimantan Selatan Suceptibility of Aedes aegypti to several insecticides groups in South Kalimantan Province. 3(2):56-62. (2018). 